RECONNAISSANCE OF GROUND-WATER RESOURCES IN THE NORTH FORK

GUNNISON RIVER BASIN, SOUTHWESTERN COLORADO

By D. J. Ackerman and Tom Brooks

U.S. GEOLOGICAL SURVEY

Water-Resources Investigations Report 85-4230

Prepared in cooperation with the

COLORADO DEPARTMENT OF NATURAL RESOURCES, DIVISION OF WATER RESOURCES

Denver, Colorado

1986 
DEPARTMENT OF THE INTERIOR

DONALD PAUL HODEL, Secretary

U.S. GEOLOGICAL SURVEY

Dallas L. Peck, Director

For additional information write to:

District Chief

U.S. Geological Survey Water Resources Division Box 25046, Mail Stop 415

Denver Federal Center

Denver, CO 80225
Copies of this report can

be purchased from:

U.S. Geological Survey

Books and Open-File Reports

Federal Center, Bldg. 41

Box 25425

Denver, CO 80225

[Telephone: (303) 236-7476] 
Page

Glossary-

Abstract-1

Introduction- 1

Purpose and scope-

Approach-

Acknowledgments-0 3

Physical setting- 3

Physiography and drainage-1 5

Climate-1. 5

Geology and structure-1 5

Availability of ground water- 7

Alluvial aquifers- 7

Bedrock aquifers- 8

Summary-0 9

Selected references-a

Supplemental data-1

\section{PLATES}

Plate 1. Map showing location of data-collection sites, North Fork Gunnison River basin, southwestern Colorado-.....-- In pocket

2. Hydrogeologic map of North Fork Gunnison River basin, southwestern Colorado-. In pocket

\section{FIGURES}

Figure 1. Map showing location of the North Fork Gunnison River basin and status of aquifer studies in western Colorado-- 2

2. System of numbering wells and springs using township, range, and section-..-

\section{TABLES}

Table 1. Rock units and their water-yielding characteristics-_-_-_. 6

2. Hydrogeologic data for wells based on drillers' records------ 12

3. Hydrogeologic data for wells- 14

4. Hydrogeologic data for springs-- 16

5. Chemical analyses of water samples- 18 


\section{GLOSSARY}

aquifer--A geologic formation, group of formations, or part of a formation that contains sufficient saturated and permeable material to yield significant quantities of water to wells and springs.

chemical quality--Includes concentration of solutes (any substance dissolved in water) and certain properties or characteristics such as hardness, sodium-adsorption ratio, percent sodium, and specific conductance.

confined aquifer--An aquifer in which ground water is confined under pressure greater than atmosphere by overlying, relatively impermeable strata. Water level in a well penetrating a confined aquifer will be above the upper boundary of the aquifer.

confining bed--A rock unit above or below an aquifer which is much less permeable than the aquifer and that restrains ground-water flow to and from adjoining units.

discharge area--An area in which subsurface water is discharged to the land surface, to surface-water bodies, or to the atmosphere.

drawdown--Decline of the water level in a well or aquifer caused by pumping or artesian flow.

infiltration--The movement of water from the land surface into the underlying soil or rock through pores or other small openings.

saturated zone--That part of the water-bearing material in which, ideally, all voids, large and small, are filled with water under pressure greater than atmospheric.

sodium-adsorption ratio (SAR)--Is the expression of relative activity of sodium ions in exchange reactions with soil. The formula used for the computation of SAR is:

$(\mathrm{Na}+)$

$\mathrm{SAR}=$

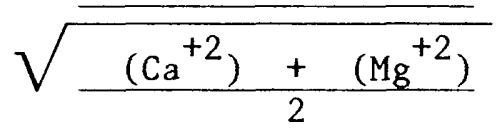

where solute concentrations are expressed in milliequivalents per liter. specific capacity--A measure of the productive capacity of the well. The specific capacity of a water well is expressed as the rate of discharge divided by the drawdown. For example: if the pumping rate is 20 gallons per minute and the drawdown is measured as 10 feet after 2 hours of pumping, the specific capacity is 2 gallons per minute per foot at the end of 2 hours:

$\frac{20 \text { gallons per minute }}{10 \text { feet }}=2$ gallons per minute per foot

specific conductance--A measure of the ability of water to conduct an electrical current, expressed in microsiemens per centimeter at $25^{\circ}$ Celsius.

water table--Surface in an unconfined water body at which the pressure is atmospheric. It is defined by the levels at which water stands in wells that penetrate the water body far enough to hold standing water. 


\section{METRIC CONVERSION FACTORS}

The inch-pound units used in this report may be converted to metric units by use of the following conversion factors:

Multiply inch-pound units

foot ( $f t)$

gallon per minute (ga1/min)

gallon per minute per foot

[(gal/min $) / \mathrm{ft}$ ]

inch (in.)

square mile $\left(\mathrm{mi}^{2}\right)$
$B y$

$$
\begin{aligned}
& 0.3048 \\
& 0.06309 \\
& 0.01923
\end{aligned}
$$

$$
25.40
$$

2.590
To obtain metric units

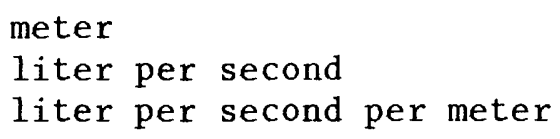

millimeter

square kilometer

To convert degrees Fahrenheit $\left({ }^{\circ} \mathrm{F}\right)$ to degrees Celsius $\left({ }^{\circ} \mathrm{C}\right)$ use the following formula: ${ }^{\circ} \mathrm{C}=\left({ }^{\circ} \mathrm{F}-32\right) 5 / 9$. To convert degrees Celsius $\left({ }^{\circ} \mathrm{C}\right)$ to degrees Fahrenheit $\left({ }^{\circ} \mathrm{F}\right)$ use the following formula: ${ }^{\circ} \mathrm{F}=9 / 5^{\circ} \mathrm{C}+32$.

The following terms and abbreviations also are used in this report: microsiemens per centimeter at $25^{\circ}$ Celsius $(\mu S / \mathrm{cm})$ and milligrams per liter (mg/L). 


\title{
RECONNAISSANCE OF GROUND-WATER \\ RESOURCES IN THE NORTH FORK GUNNISON \\ RIVER BASIN, SOUTHWESTERN COLORADO
}

By D. J. Ackerman and Tom Brooks

\begin{abstract}
Aquifers of large areal extent in the North Fork Gunnison River basin are found in the alluvium and bedrock. Alluvial aquifers yielded water with dissolved-solids concentrations ranging from 43 to 2,300 milligrams per liter. Dissolved-solids concentrations of water samples from the Mesaverde Formation of Late Cretaceous age and the Dakota Sandstone and Burro Canyon Formations of Late and Early Cretaceous age ranged from 56 to 3,200 milligrams per liter. Dissolved-solids concentrations of water samples from Mancos Shale ranged from 1,800 to 8,200 milligrams per liter.

Most wells in the North Fork Gunnison River basin are at altitudes below 7,500 feet, yield from 2 to 40 gallons per minute and are completed in alluvial sand and gravel, sandstone, or fractured bedrock. Springs generally are at altitudes above 7,000 feet, discharge from perched water tables at geologic contacts, have calcium magnesium bicarbonate water types, and are much less saline than water from wells.
\end{abstract}

\section{INTRODUCTION}

The need for additional water supplies in western Colorado is increasing as population, industrial and agriculture development, and recreational activities increase. The U.S. Geological Survey, in cooperation with the Colorado Department of Natural Resources, Division of Water Resources, Office of the State Engineer, has been appraising the ground-water resources in areas of increased water demand, such as the North Fork Gunnison River basin, to determine if these resources can be used to meet, or to partly meet, current and future demands for additional water. The location of the North Fork Gunnison River basin and the location of similar ground-water resources in western Colorado are shown in figure 1. 


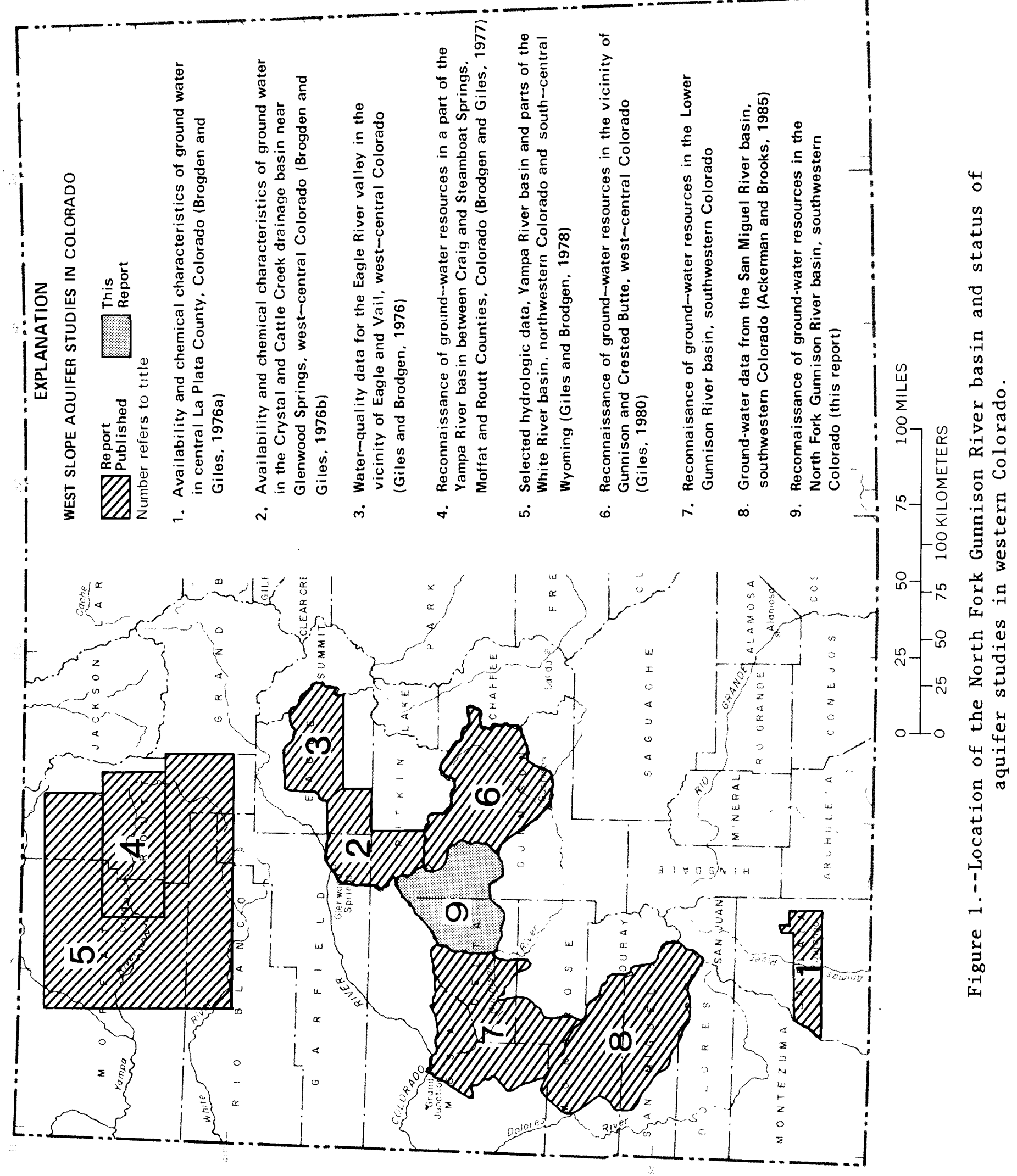




\section{Purpose and Scope}

The purpose of this report is to present ground-water data to help in the efficient development, appropriation, and management of the water resources of the North Fork Gunnison River basin in southwestern Colorado. The data in this report are used to describe aquifers in the North Fork Gunnison River basin. Most data in this report were collected between 1977 and 1982 .

Data for this report were compiled from interviews with well and spring users, drillers' records of water wells, completion records and logs for oil and gas test wells, geologic maps, and chemical analyses of water samples from wells and springs. The data reported here consist of: (1) Hydrologic information from wells based on drillers' records, (2) hydrogeologic information from wells and springs, and (3) chemical analyses of water samples from wells and springs. Data for wells and springs are given in tables 2, 3, 4, and 5 in the "Supplemental Data" section at the back of this report. The system of numbering wells is explained in figure 2. All data sites are shown on plate 1 (in pocket).

\section{Approach}

Depth to water was measured in wells by using a steel tape, electrical tape, or was taken from recorded data. Discharges from wells were taken from drillers' records and discharges from springs were measured by volumetric measurements with time. Well and spring water samples were collected and analyzed for major chemical constituents and trace elements. The geologic formations that wells were completed in or that springs issue from was determined from well drillers' records and geologic maps.

\section{Acknowledgments}

Residents of the basin provided information about their wells and springs, permitted measurements to be made, and allowed samples to be collected. Donald Fawcett, Andrew Wacinski, and Stanley Zawistowski, employees of the Office of the State Engineer (during the data collection 1977-1982), assisted in the collection and compilation of data.

\section{PHYSICAL SETTING}

Most residents in the North Fork Gunnison River basin live at lower altitudes and in or near small towns. The two largest towns are Paonia, population 1,425, and Hotchkiss, population 849 (U.S. Bureau of the Census, 1981). The economy in the basin is mainly agricultural and mining, with some lumbering and tourism. 


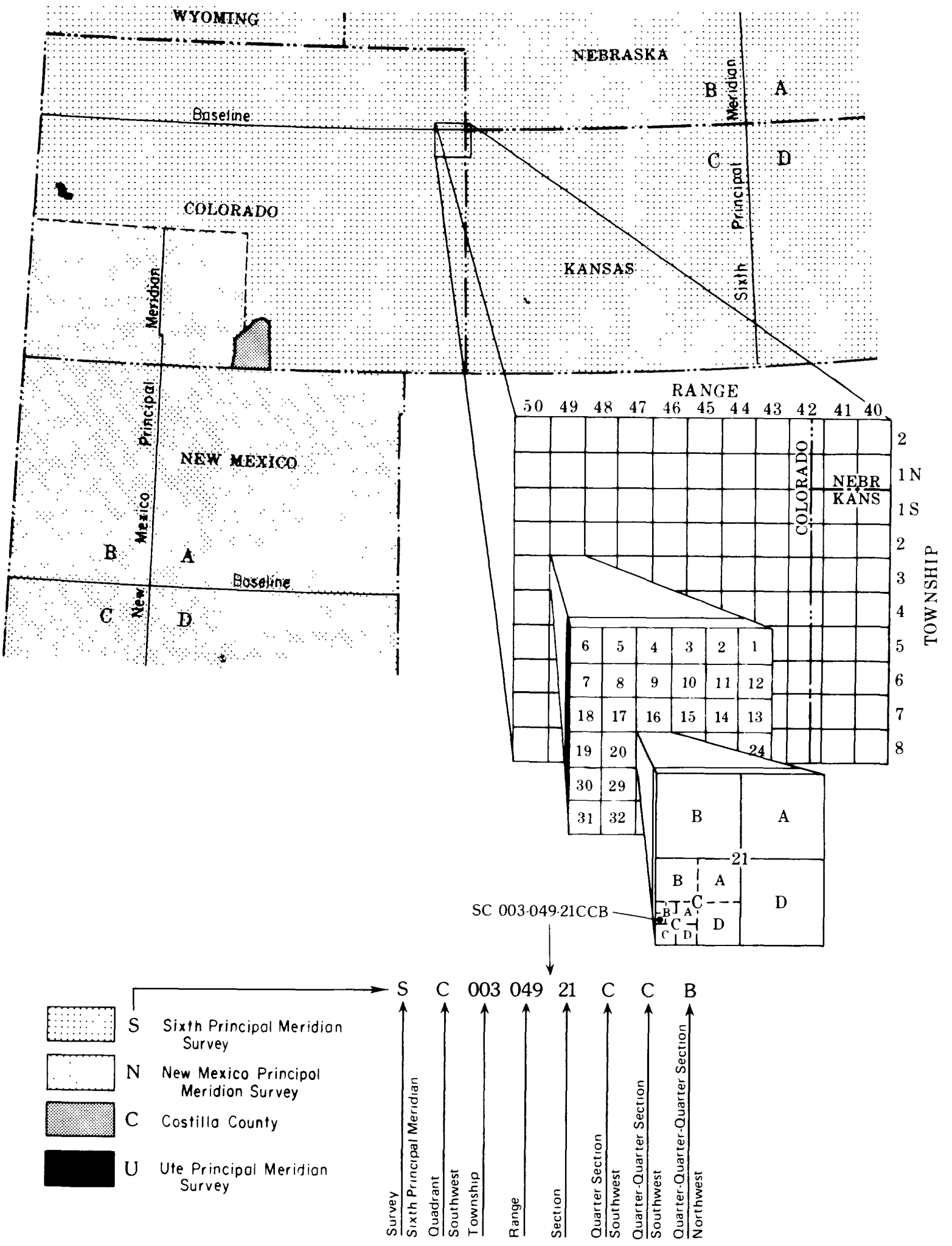

Figure 2.--System of numbering wells and springs using township, range, and section. 
The town of Paonia uses springs that issue from alluvium, and the town of Hotchkiss uses surface water from Leroux Creek for public drinking water. Ground water is used domestically and for irrigation and livestock in more remote areas.

\section{Physiography and Drainage}

The North Fork Gunnison River basin lies in both the Canyon Lands section of the Colorado Plateau physiographic province and in the Uinta Basin physiographic province (Fenneman, 1946). The topography ranges from high, glaciated peaks to deeply eroded valleys.

The headwaters of the North Fork Gunnison River and its major tributaries are within the mountainous borders of the basin. The highest point in the basin is 13,058-ft Owen Peak near the eastern border. The lowest point in the basin is at the confluence of the North Fork Gunnison and Gunnison Rivers, at an elevation of about $5,100 \mathrm{ft}$ at the southwestern corner. The streams of the basin are in rugged terrain and broad, low-relief valleys. The drainage area of the North Fork Gunnison River is 1,002 $\mathrm{mi}^{2}$.

\section{Climate}

The variable topography is related to the variable climate in the North Fork Gunnison River basin. Average annual precipitation is less than 12 in. near Hotchkiss in the lower part of the valley and is about 40 in. on the mountains in the eastern part of the basin (Iorns and others, 1965, p1. 4). Temperatures typically range from less than $-30^{\circ} \mathrm{F}$ in the mountains in January to more than $95^{\circ} \mathrm{F}$ at Hotchkiss near the confluence of the North Fork Gunnison and Gunnison Rivers in July. The average number of frost-free days ranges from about 130 days in the lowest areas to less than 60 days in the mountains. Paonia's altitude is $5,580 \mathrm{ft}$, has an average annual precipitation of $14.3 \mathrm{in}$., and an average annual air temperature of $49^{\circ} \mathrm{F}$ (1950-1979 period of record, U.S. National Climatic Data Center, 1950-79).

\section{Geology and Structure}

Rock units exposed in the North Fork Gunnison River basin range in age from Late Jurassic to Quaternary. Major rock types are sedimentary sandstone and shale, igneous intrusive and extrusive rocks, and alluvial sand and gravel. The age, thickness, lithology, and water-yielding characteristics of the rock units are summarized in table 1 . The areal extent of exposed rock units is shown on plate 2 (in pocket). On plate 2 , some of the rock units are grouped with other adjacent rock units believed to be part of the same aquifer system or rock units of similar water-yielding characteristics. For instance, the Dakota Sandstone and Burro Canyon Formation are grouped together because they are believed to be part of the same aquifer system. 
Table 1.--Rock units and their water-yielding characteristics

$$
[\mathrm{gal} / \mathrm{min}=\text { gallon per minute] }
$$

\begin{tabular}{|c|c|c|c|c|c|c|}
\hline \multirow{2}{*}{\begin{tabular}{|c}
$\begin{array}{c}\text { System } \\
\text { or } \\
\text { series }\end{array}$ \\
Quaternary
\end{tabular}} & \multicolumn{2}{|c|}{ Rock unit } & \multicolumn{2}{|c|}{$\begin{array}{l}\text { Maximum } \\
\text { thickness } \\
\text { (feet) }\end{array}$} & \multirow{2}{*}{$\begin{array}{c}\begin{array}{c}\text { Predominant } \\
\text { lithology }\end{array} \\
\begin{array}{c}\text { Silt, sand, and } \\
\text { gravel }\end{array}\end{array}$} & \multirow{2}{*}{$\begin{array}{l}\text { Water-yielding } \\
\text { characteristics } \\
\text { Well yields gen- } \\
\text { erally range } \\
\text { from } 2 \text { to } 40 \\
\text { gal/min. }\end{array}$} \\
\hline & \multicolumn{3}{|c|}{$\begin{array}{l}\text { Alluvium landslide, } \\
\text { talus, colluvium, } \\
\text { glacial drift, } \\
\text { and terrace } \\
\text { gravels }\end{array}$} & $100 ?$ & & \\
\hline \multirow[t]{5}{*}{ Tertiary } & \multicolumn{3}{|c|}{$\begin{array}{l}\text { Volcanic rocks- } \\
\text { intrusive and } \\
\text { extrusive }\end{array}$} & -- & $\begin{array}{l}\text { Dense black } \\
\text { basalt, } \\
\text { granodiorites } \\
\text { and andesite } \\
\text { basalt }\end{array}$ & $\begin{array}{l}\text { Water quantity is } \\
\text { variable depend- } \\
\text { ing on degree of } \\
\text { fracturing. No } \\
\text { known wells. }\end{array}$ \\
\hline & \multicolumn{3}{|c|}{ Uinta Formation } & $?$ & \multirow{3}{*}{$\begin{array}{l}\text { Siltstone, sand- } \\
\text { stone, or marl- } \\
\text { stone }\end{array}$} & \multirow{3}{*}{$\begin{array}{l}\text { No data available. } \\
1 \text { to } 5 \text { gal/min } \\
\text { may be expected } \\
\text { from sandstone. }\end{array}$} \\
\hline & \multirow{2}{*}{$\begin{array}{l}\text { Green } \\
\text { River } \\
\text { Forma- } \\
\text { tion }\end{array}$} & \multirow{2}{*}{\multicolumn{2}{|c|}{$\begin{array}{l}\text { Parachute } \\
\text { Creek Member }\end{array}$}} & $400 ?$ & & \\
\hline & & & & & & \\
\hline & \multicolumn{3}{|c|}{ Wasatch Formation } & 3400 & $\begin{array}{l}\text { Variegated clay- } \\
\text { stone, siltstone, } \\
\text { sandstone, sand- } \\
\text { stone lignite, } \\
\text { and conglomerate }\end{array}$ & $\begin{array}{l}\text { Limited data indi- } \\
\text { cate as much as } \\
25 \text { gal/min avail- } \\
\text { able from sand- } \\
\text { stone and } \\
\text { conglomerate. }\end{array}$ \\
\hline \multirow[t]{2}{*}{$\begin{array}{l}\text { Upper } \\
\text { Cretaceous }\end{array}$} & \multicolumn{3}{|c|}{ Mesaverde Formation } & 3000 & $\begin{array}{l}\text { Sandstone, shale, } \\
\text { and coal }\end{array}$ & $\begin{array}{l}\text { Limited data indi- } \\
\text { cate yields of } \\
\text { less than } 10 \\
\text { gal/min. }\end{array}$ \\
\hline & \multicolumn{3}{|c|}{ Mancos Shale } & 4500 & $\begin{array}{l}\text { Dark gray carbon- } \\
\text { aceous marine } \\
\text { shale }\end{array}$ & $\begin{array}{l}\text { Water quantity } \\
\text { depends on degree } \\
\text { of fracturing. A } \\
\text { confining bed for } \\
\text { underlying sand- } \\
\text { stones. }\end{array}$ \\
\hline $\begin{array}{l}\text { Upper and } \\
\text { Lower } \\
\text { Cretaceous }\end{array}$ & \multicolumn{3}{|c|}{$\begin{array}{l}\text { Dakota Sandstone } \\
\text { and Burro Canyon } \\
\text { Formations, un- } \\
\text { differentiated }\end{array}$} & 250 & $\begin{array}{l}\text { Interbedded sand- } \\
\text { stone, conglom- } \\
\text { erate, shale and } \\
\text { coal }\end{array}$ & $\begin{array}{l}\text { Well yields of } \\
\text { more than } 10 \mathrm{gal} / \\
\text { min are to be ex- } \\
\text { pected. }\end{array}$ \\
\hline $\begin{array}{l}\text { Upper } \\
\text { Jurassic }\end{array}$ & \multicolumn{3}{|c|}{ Morrison Formation } & 580 & $\begin{array}{l}\text { Mudstone and sand- } \\
\text { stone. }\end{array}$ & $\begin{array}{c}\text { No data are avail- } \\
\text { able. }\end{array}$ \\
\hline
\end{tabular}


Most rock units in the North Fork Gunnison River basin dip about 2 to 8 degrees to the north or northwest from the Gunnison uplift into the Piceance basin. There are many small structures and faults in the basin. The geology is complex in the southeast one-third of the basin because there are sills, dikes, laccoliths, and stocks (igneous intrusions).

\section{AVAILABILITY OF GROUND WATER}

\section{Alluvial Aquifers}

Alluvium deposits consisting of sand, silt, and gravel of Quaternary age are aquifers throughout the basin and usually are less than $100 \mathrm{ft}$ thick. The thickest and most commonly saturated deposits generally are the alluvium of the eroded valleys. Alluvium and eolian deposits on mesas usually are thin. Alluvium, talus, and colluvium on steep slopes are only seasonally saturated.

Wells completed in alluvium have reported well yields from 1 to $150 \mathrm{gal} / \mathrm{min}$ with an average of about $20 \mathrm{gal} / \mathrm{min}$ (table 2). The water quality of most wells completed in alluvium aquifers is more suitable for domestic and agricultural use than wells completed in bedrock aquifers.

Springs are at the base of colluvial, talus, or landslide deposits on steep slopes. Spring flows are commonly seasonal, lasting from spring to midsummer. Springs primarily are recharged from infiltration of precipitation. Spring discharges were measured at 18 sites where they issued from alluvial aquifers with rates from 0.02 to. $20 \mathrm{gal} / \mathrm{min}$ and averaged about $5 \mathrm{gal} / \mathrm{min}$ (table 4 ).

Four wells completed in alluvium and glacial deposits had specific conductance values from 171 to $2,700 \mu \mathrm{S} / \mathrm{cm}$ (table 5) and dissolved-solids concentrations of 110 to $2,300 \mathrm{mg} / \mathrm{L}$. The dominant cation was calcium and the dominant anion was bicarbonate. There were 18 springs that issued from alluvium and glacial deposits with specific conductance values ranging from 62 to $875 \mu \mathrm{S} / \mathrm{cm}$ and averaging $451 \mu \mathrm{S} / \mathrm{cm}$. Dissolved solids for 15 water samples collected from springs ranged from 43 to $760 \mathrm{mg} / \mathrm{L}$ and averaged $323 \mathrm{mg} / \mathrm{L}$. The dominant cation was calcium and the dominant anion was bicarbonate. Sulfate, dissolved solids, and manganese concentrations exceeded the U.S. Environmental Protection Agency drinking water regulations (1977b) in some water samples.

Because the flow paths and residence times of water in the alluvial aquifers are shorter than in bedrock aquifers, the bedrock aquifers generally have larger concentrations of dissolved solids. Alluvial aquifers probably are hydraulically connected with adjacent consolidated bedrock aquifers. 


\section{Bedrock Aquifers}

Sandstone, conglomerate, and fractured bedrock of differing lithologies are bedrock aquifers in most of the basin. The primary bedrock aquifers in the North Fork Gunnison River basin are the Burro Canyon Formation and the Dakota Sandstone of Early and Late Cretaceous age. Fine-grained rock, such as shale, may yield water where fractured or may contain sandstone lenses which may contain water. Finer-grained rock confine adjacent aquifers. Bedrock aquifers generally are confined except near outcrops. Fractured coal seams in the Mesaverde Formation contain water near outcrops.

One well completed in the Dakota Sandstone has a reported yield of $20 \mathrm{gal} / \mathrm{min}$ and flows at the surface (table 2). The Dakota Sandstone generally is deeper than $2,000 \mathrm{ft}$ below land surface in all but the extreme southeastern corner of the basin.

Four of the wells completed in the Mancos Shale yield from 0.5 to $15 \mathrm{gal} / \mathrm{min}$, and two are dry (table 2). This formation generally yields little water and has unsuitable water for domestic or agricultural uses.

Three wells completed in the Mesaverde Formation of Late Cretaceous age yield from 2 to $3 \mathrm{gal} / \mathrm{min}$ (table 2). The sandstone and shale of the Mesaverde Formation are less permeable than fractured coal seams.

In areas of Tertiary igneous intrusives and basalt flows, no wells have been drilled. Two wells completed in the Wasatch Formation have reported yields of 15 and $26 \mathrm{gal} / \mathrm{min}$, although the formation generally is an aquitard based on lithology (table 2). The Wasatch Formation is exposed over much of the basin; higher altitudes and inaccessible locations limit development.

The depth of wells completed in bedrock ranges from 10 to $2,150 \mathrm{ft}$ (table 3). Wells that were completed for domestic use are generally less than $150 \mathrm{ft}$ deep, and wells completed for monitoring ground-water levels near mining areas are generally from 500 to $2,000 \mathrm{ft}$ deep.

Spring discharges issuing from the Mancos Shale and the Mesaverde and Wasatch Formations were measured. Four spring discharges from the Mancos Shale were $1,5,5$, and $30 \mathrm{gal} / \mathrm{min}$ (table 4). Three spring discharges from the Mesaverde Formation were 5,10 and $25 \mathrm{gal} / \mathrm{min}$. Three spring discharges from the Wasatch Formation were 1,1 , and $20 \mathrm{gal} / \mathrm{min}$. 
Specific-conductance values for 8 wells completed in bedrock aquifers averaged $3,212 \mu \mathrm{S} / \mathrm{cm}$. Concentrations of dissolved solids for 7 wells averaged $2,569 \mathrm{mg} / \mathrm{L}$ and ranged from 490 to $8,200 \mathrm{mg} / \mathrm{L}$ (table 5). The dominant cation in most well-water samples was sodium, and the dominant anion was bicarbonate or sulfate. Concentrations of flouride exceeded national interim primary drinking water regulations established by the U.S. Environmental Protection Agency (1977a) in some water samples collected from wells completed in bedrock aquifers. Concentrations of sulfate, chloride, dissolved solids, iron, and manganese in some water samples exceeded the national secondary drinking water regulations established by the U.S. Environmental Protection Agency (1977b).

Four springs issuing from bedrock had specific-conductance values of $3,100,3,500,52$, and $585 \mu \mathrm{S} / \mathrm{cm}$ and dissolved-solids concentrations of 3,100 , $4,300,56$, and $370 \mathrm{mg} / \mathrm{L}$. The dominant cation was calcium, and the dominant anion was sulfate in water samples. Concentrations of selenium exceeded the U.S. Environmental Protection Agency interim primary drinking water regulations (1977a) in two water samples, and concentrations of sulfate, dissolved solids, and manganese exceeded the U.S. Environmental Protection Agency secondary drinking water regulations (1977b) in some water samples.

\section{SUMMARY}

The primary aquifers in the North Fork Gunnison River basin are alluvial and bedrock. Alluvial aquifers are thickest in valley bottoms and usually less than $100 \mathrm{ft}$ thick. Dissolved-solids concentrations ranged from 43 to $2,300 \mathrm{mg} / \mathrm{L}$ in water from alluvial and glacial deposit aquifers. Well yields averaged about $20 \mathrm{gal} / \mathrm{min}$.

Alluvial water quality was usually more suitable for domestic and agricultural use than bedrock ground water. Alluvial aquifers probably are hydraulically connected with adjacent bedrock aquifers and intermixing of the two aquifers is expected.

Dissolved-solids concentrations of water samples from bedrock aquifers ranged from 56 to $8,200 \mathrm{mg} / \mathrm{L}$. The dominant cation was sodium, and the dominant anion was bicarbonate or sulfate. Concentrations of sulfate, chloride, fluoride, dissolved solids, iron, manganese, and selenium in some water samples exceeded U.S. Environmental Protection Agency drinking water regulations $(1977 \mathrm{a}, 1977 \mathrm{~b})$. Well yields up to $26 \mathrm{gal} / \mathrm{min}$ are reported. 


\section{SELECTED REFERENCES}

Ackerman, D.J., and Brooks, Tom, 1985, Ground-water data from the San Miguel River basin, southwestern Colorado: U.S. Geological Survey Open-File Report 85-191, $19 \mathrm{p}$.

Brogden, R.F., and Giles, T.F., 1976a, Availability and chemical characteristics of ground water in central La Plata County, Colorado: U.S. Geological Survey Water-Resources Investigations 76-69, 1 sheet. $1976 \mathrm{~b}$, Availability and chemical quality of ground water in the Crystal River and Cattle Creek drainage basin near Glenwood Springs, west-central Colorado: U.S. Geological Survey Water-Resources Investigations 76-70, 1 sheet:

1977, Reconnaissance of ground-water resources in a part of the Yampa River basin, between Craig and Steamboat Springs, Moffat and Routt Counties, Colorado: U.S. Geological Survey Water-Resources Investigations $77-4,1$ sheet.

Brooks, Tom, and Ackerman, D.J., 1985, Reconnaissance of ground-water resources in the lower Gunnison River basin, southwestern Colorado: U.S. Geological Survey Water-Resources Investigations Report 84-4185, $30 \mathrm{p}$.

Fenneman, N.M., 1946, Physical divisions of the United States: U.S. Geological Survey map, scale 1:7,000,000 (reprinted 1964).

Giles, T.F., 1980, Reconnaissance of ground-water resources in the vicinity of Gunnison and Crested Butte, west-central Colorado: U.S. Geological Survey Open-File Report 80-12, 2 sheets.

Giles, T.F., and Brogden, R.F., 1976, Water-quality data for the Eagle River Valley in the vicinity of Eagle and Vail, west-central Colorado, U.S. Geological Survey Open-File Report 76-812, scale 1:125,000. 1978, Selected hydrologic data, Yampa River basin, and parts of the White River basin, northwestern Colorado and south-central Wyoming: U.S. Geological Survey Open-File Report 78-23, 91 p.

Iorns, W.V., Hembree, C.H., and Oakland, G.L., 1965, Water resources of the Upper Colorado River Basin--Technical report: U.S. Geological Survey Professional Paper 441, 370 p.

Tweto, Ogden, Moench, R.H., and Reed, J.C., Jr., 1976, Geologic map of the Leadville $1^{\circ} \times 2^{\circ}$ quadrangle, northwestern Colorado: U.S. Geological Survey Miscellaneous Field Studies Map MF-760, scale 1:250,000.

Tweto, Ogden, Steven, W.J., Hail, W.J., Jr., and Moench, R.H., 1976, Geologic map of the Montrose $1^{\circ} \times 2^{\circ}$ quadrangle, southwestern Colorado: U.S. Geological Survey Miscellaneous Field Studies Map MF-761, scale $1: 250,000$.

U.S. Bureau of the Census, 1981,1980 census of population, number of inhabitants, Colorado: U.S. Bureau of the Census Report PC (1)-A 7, $30 \mathrm{p}$.

U.S. Environmental Protection Agency, 1977a, National interim primary drinking water regulations: Washington, D.C., EPA-57019-76-003, 159 p. $1977 \mathrm{~b}$, National secondary drinking water regulations (proposed): Federal Register, v. 42, no. 62, Mar. 31, Part I, p. 17143-17147.

U.S. National Climatic Data Center, 1950-1979 Climatological data, Annual summary, Colorado, Paonia station: Asheville, N.C. 
SUPPLEMENTAL DATA 
Table 2.--Hydrologic data for wells from drillers' records

\begin{tabular}{|c|c|c|c|c|c|c|c|}
\hline $\begin{array}{c}\text { Map } \\
\text { location } \\
\text { number } \\
\text { (see } \\
\text { plate 1) }\end{array}$ & $\begin{array}{c}\text { Local } \\
\text { identifier } \\
\text { (see } \\
\text { figure 2) }\end{array}$ & $\begin{array}{l}\text { State } \\
\text { well } \\
\text { permit } \\
\text { number }\end{array}$ & Principal aquifer & $\begin{array}{c}\text { Well } \\
\text { depth } \\
\text { (feet) }\end{array}$ & $\begin{array}{l}\text { Depth } \\
\text { to } \\
\text { water } \\
\text { (feet) }\end{array}$ & $\begin{array}{c}\text { Well } \\
\text { yield } \\
\text { (gallons } \\
\text { per minute) }\end{array}$ & $\begin{array}{c}\text { Specific } \\
\text { capacity } \\
\text { (gallons per } \\
\text { minute per foot) }\end{array}$ \\
\hline 1 & $\mathrm{SC} 01008901 \mathrm{CB}$ & $3466 \mathrm{~F}$ & Alluvium & 130 & 65 & 8 & -- \\
\hline 2 & SC01108918ADD & 83771 & Alluvium & 93 & 58 & 40 & 2.50 \\
\hline 3 & $\mathrm{SC} 01108929 \mathrm{BBA}$ & 72652 & Alluvium & 150 & 11 & 7 & .23 \\
\hline 4 & $S C 01108002 D C D$ & 62475 & Alluvium & 105 & 80 & 6 & .60 \\
\hline 5 & SC01109010BBB & 66084 & Alluvium & 30 & 10 & 15 & 1.50 \\
\hline 6 & SC01109011CAA & 66085 & Alluvium & 40 & 8 & 15 & 1.00 \\
\hline 7 & SC01109014ACA & 72500 & Wasatch Formation & 41 & 18 & 15 & 2.14 \\
\hline 8 & $\mathrm{SC} 01109130 \mathrm{AC}$ & 67350 & Alluvium & 55 & 7 & 15 & 2.50 \\
\hline 9 & $S C 01308901 \mathrm{AD}$ & 34667 & Wasatch Formation & 38 & 6 & 26 & 2.17 \\
\hline 10 & $S C 01308902 D C$ & 80370 & Alluvium & 30 & 5 & 20 & 6.67 \\
\hline 11 & $\mathrm{SCO} 1308907 \mathrm{BD}$ & 61147 & Alluvium & 30 & 13 & 10 & 1.00 \\
\hline 12 & SC01308910DA & 43469 & Alluvium & 63 & -- & 25 & 1.14 \\
\hline 13 & $\mathrm{SC} 01308911 \mathrm{BA}$ & 89054 & Alluvium & 35 & 11 & 15 & 3.00 \\
\hline 14 & SC01309010CD & 80254 & Alluvium & 37 & 7 & 50 & 7.14 \\
\hline 15 & SC01309011CD & 2146 & Alluvium & 55 & 51 & 20 & -- \\
\hline 16 & $\mathrm{SC} 01309106 \mathrm{BBC}$ & 11687 & Alluvium & 32 & 22 & 6 & 3.00 \\
\hline 17 & SC01309113DD & 13512 & Mesaverde Formation & 80 & 36 & 2 & .04 \\
\hline 18 & SC01309114DAA & 58396 & Alluvium & 30 & 15 & 15 & 3.00 \\
\hline 19 & $\mathrm{SC} 01309115 \mathrm{CC}$ & 50633 & Alluvium & 35 & 8 & 36 & 4.50 \\
\hline 20 & SC01309121CC & 43927 & Alluvium & 40 & 23 & 21 & 3.50 \\
\hline 21 & SC01309121CD & 59487 & Alluvium & 55 & 9 & 7 & .44 \\
\hline 22 & SC01309123CBA & 61146 & Alluvium & 112 & 70 & 5 & .29 \\
\hline 23 & $\mathrm{SC} 01309128 \mathrm{BA}$ & 82911 & Alluvium & 58 & 27 & 30 & 6.00 \\
\hline 24 & $\mathrm{SC} 01309129 \mathrm{BC}$ & 20906 & Alluvium & 110 & Dry & Dry & -- \\
\hline 25 & SC01309129DA & 61898 & Alluvium & 45 & 18 & 30 & 1.30 \\
\hline 26 & Sc01309131Cc & 29365 & Alluvium & 14 & 2 & 5 & 2.50 \\
\hline 27 & SC01309132CD & 53950 & Alluvium & 30 & 13 & 30 & 6.00 \\
\hline 28 & SC01309213BCA & $22422 \mathrm{~F}$ & Alluvium & 97 & 3 & 37 & -- \\
\hline 29 & $\mathrm{SC01309232CC}$ & 33528 & Alluvium & 30 & 10 & 40 & 6.67 \\
\hline 30 & $\mathrm{SC} 01309327 \mathrm{BBB}$ & 54989 & Alluvium & 80 & 4 & 24 & 1.20 \\
\hline 31 & SC01309332CBA & 76602 & Alluvium & 265 & 111 & 2 & .03 \\
\hline 32 & SC01409007AC & 11392 & Mesaverde Formation & 53 & 33 & 3 & -- \\
\hline 33 & SC01409008AC & 92019 & Mesaverde Formation & 140 & 110 & 2 & -- \\
\hline 34 & SC01409102BAC & 9155 & Alluvium & 36 & 14 & 3 & -- \\
\hline 35 & SC01409104DBC & 14620 & Alluvium & 15 & 5 & 5 & -- \\
\hline 36 & $\mathrm{SC} 01409106 \mathrm{AB}$ & 27023 & Alluvium & 18 & 7 & 18 & 3.00 \\
\hline 37 & SC01409106BBB & 22492 & Alluvium & 23 & 8 & 5 & -- \\
\hline 38 & SC01409107CCD & 14409 & Mancos Shale & 70 & 10 & 5 & -- \\
\hline 39 & $\mathrm{SC} 01409108 \mathrm{AC}$ & 57436 & Alluvium & 48 & 10 & 15 & .75 \\
\hline 40 & SC01409109DAC1 & 30520 & Mancos Shale & 66 & 20 & .5 & .01 \\
\hline
\end{tabular}


Table 2.--Hydrologic data for wells from drillers' records--Continued

\begin{tabular}{|c|c|c|c|c|c|c|c|}
\hline $\begin{array}{l}\text { Map } \\
\text { location } \\
\text { number } \\
\text { (see } \\
\text { plate 1) }\end{array}$ & $\begin{array}{c}\text { Local } \\
\text { identifier } \\
\text { (see } \\
\text { figure 2) }\end{array}$ & $\begin{array}{l}\text { State } \\
\text { well } \\
\text { permit } \\
\text { number }\end{array}$ & Principal aquifer & $\begin{array}{l}\text { Well } \\
\text { depth } \\
\text { (feet) }\end{array}$ & $\begin{array}{l}\text { Depth } \\
\text { to } \\
\text { water }\end{array}$ & $\begin{array}{c}\text { Well } \\
\text { yield } \\
\text { (gallons } \\
\text { per minute) }\end{array}$ & $\begin{array}{c}\text { Specific } \\
\text { capacity } \\
\text { (gallons per } \\
\text { minute per foot) }\end{array}$ \\
\hline 41 & $\mathrm{SC} 01409116 \mathrm{DAB}$ & 8654 & Alluvium & 26 & 15 & 9 & -- \\
\hline 42 & $\mathrm{SC} 01409118 \mathrm{DCC}$ & 9194 & Alluvium & 40 & 18 & 3 & 0.38 \\
\hline 43 & $\mathrm{SC} 01409119 \mathrm{BD}$ & $2777 \mathrm{~F}$ & Mancos Shale & 125 & Dry & Dry & -- \\
\hline 44 & SC01409129CD & 15731 & Alluvium & 27 & -- & 5 & -- \\
\hline 45 & SC01409201ACC & 19786 & Alluvium & 31 & 15 & 5 & 2.50 \\
\hline 46 & SC01409202CAA1 & 19684 & Alluvium & 21 & 13 & 6 & 1.50 \\
\hline 47 & SC01409206DA & 61704 & Alluvium & 95 & 59 & 2.5 & .012 \\
\hline 48 & SC01409209DBD & 39709 & Alluvium & 40 & 23 & 15 & 2.50 \\
\hline 49 & $\mathrm{SC} 01409210 \mathrm{CCC}$ & 23437 & Alluvium & 49 & 36 & 5 & -- \\
\hline 50 & SC01409211BAA & 26941 & Alluvium & 41 & 7 & 20 & 10 \\
\hline 51 & $\mathrm{SC} 01409212 \mathrm{AB}$ & 46540 & Alluvium & 40 & 15 & 30 & 10 \\
\hline 52 & $\mathrm{SC} 01409215 \mathrm{CAB}$ & $12260 \mathrm{~F}$ & Alluvium & 28 & 4 & 150 & 37.50 \\
\hline 53 & $\mathrm{SC} 01409216 \mathrm{CA}$ & $21279 F$ & Dakota Sandstone & 1,386 & Artesian & 20 & -- \\
\hline 54 & SC01409217DAC & 61704 & Alluvium & 95 & 59 & 2.5 & .12 \\
\hline 55 & $\mathrm{SC} 01409219 \mathrm{ABC}$ & 68086 & Alluvium & 50 & 31.5 & 15 & 3.75 \\
\hline 56 & SC01409220ADB & 92582 & Alluvium & 35 & 14 & 20 & 2.50 \\
\hline 57 & SC01409229BCC & 89904 & Alluvium & 40 & 17.5 & 30 & 8.57 \\
\hline 58 & SC01409230CDB & 22597 & Alluvium & 55 & 21.5 & 30 & 8.57 \\
\hline 59 & SC01409304BAA & 56599 & Alluvium & 110 & 58.5 & 30 & 1.52 \\
\hline 60 & SC01409305BBB & 25740 & Alluvium & 75 & 45 & 5 & .25 \\
\hline 61 & $\mathrm{SC} 01409305 \mathrm{CB}$ & 74961 & Mancos Shale & 142 & 91 & 15 & 1.50 \\
\hline 62 & $\mathrm{SC} 01409312 \mathrm{ADC}$ & 17838 & Mancos Shale & 42 & -- & Dry & -- \\
\hline 63 & SC01409322DAB & 25412 & Alluvium & 70 & 39 & 5 & .17 \\
\hline 64 & $\mathrm{SC} 01409325 \mathrm{ABA}$ & $20549 \mathrm{~F}$ & Alluvium & 60 & 25 & 100 & -- \\
\hline 65 & $\mathrm{SC} 01409326 \mathrm{BD}$ & 5007 & Alluvium & 43 & -- & Dry & -- \\
\hline 66 & SC01409326DD & 90443 & Alluvium & 180 & 115 & 5 & -- \\
\hline 67 & $\mathrm{SC} 01409328 \mathrm{AD}$ & 77728 & Alluvium & 110 & 85 & 15 & 3.00 \\
\hline 68 & SC01409333CBC & $16538 \mathrm{~F}$ & Alluvium & 60 & 22 & 70 & 10 \\
\hline 69 & SC01508922CBA & $12676 \mathrm{~F}$ & Alluvium & 65 & 40 & 18 & 4.50 \\
\hline 70 & SC01509121DA & 12726 & Alluvium & 105 & 80 & 1 & .05 \\
\hline 71 & SC01509129ABA & 87144 & Mancos Shale & 160 & 40 & 2.5 & .02 \\
\hline 72 & $\mathrm{SC} 01509303 \mathrm{CB}$ & 83573 & Alluvium & 67 & 32 & 28 & 7.00 \\
\hline
\end{tabular}


Table 3.--Hydrogeologic data for wells

\begin{tabular}{|c|c|c|c|c|c|c|c|c|}
\hline $\begin{array}{l}\text { Map } \\
\text { location } \\
\text { number } \\
\text { (see } \\
\text { plate } \\
\text { 1) }\end{array}$ & $\begin{array}{l}\text { Local } \\
\text { identifier } \\
\text { (see } \\
\text { figure 2) }\end{array}$ & Owner & Principal aquifer & $\begin{array}{c}\text { Altitude } \\
\text { (feet) }\end{array}$ & $\begin{array}{c}\text { Well } \\
\text { depth } \\
\text { (feet) }\end{array}$ & $\begin{array}{l}\text { Depth } \\
\text { to } \\
\text { water } \\
\text { (feet) }\end{array}$ & $\begin{array}{l}\text { Date } \\
\text { water } \\
\text { level } \\
\text { measured }\end{array}$ & $\begin{array}{l}\text { Date } \\
\text { sampled } \\
\text { (see } \\
\text { table 5) }\end{array}$ \\
\hline 73 & SC01108920CCD1 & -- & -- & 6,989 & 150 & 11.00 & $07 / 13 / 1978$ & -- \\
\hline 74 & SC01208905BAA 1 & -- & -- & 6,700 & 46 & -- & -- & -- \\
\hline 75 & $\mathrm{SC} 01308907 \mathrm{BDB} 1$ & Sell, Marion & Alluvium & 6,225 & 30 & 6.00 & $05 / / 1974$ & $05 / 29 / 1974$ \\
\hline 76 & SC01309010DCC1 & Western Slope Realty Co. & Mesaverde Formation & 6,105 & 63 & 30.00 & $05 / / 1974$ & $05 / 29 / 1974$ \\
\hline 77 & SC01309106DAC1 & Colorado Westmoreland Inc. & Mesaverde Formation & 7,950 & 1,500 & $1,355.00$ & $06 / 04 / 1982$ & -- \\
\hline 78 & SC01309107BBA 1 & Colorado Westmoreland Inc. & Mesaverde Formation & 8,300 & 1,975 & $1,750.00$ & $08 / 20 / 1982$ & -- \\
\hline 79 & $\mathrm{SC} 01309107 \mathrm{CDC} 1$ & Colorado Westmoreland Inc. & Mesaverde Formation & 8,715 & 2,150 & $2,029.00$ & $07 / 20 / 1982$ & -- \\
\hline 80 & SC01309107DCA1 & Colorado Westmoreland Inc. & Mesaverde Formation & 8,231 & 1,694 & $1,390.00$ & $06 / 04 / 1982$ & -- \\
\hline 81 & SC01309108CBB 1 & Colorado Westmoreland Inc. & Mesaverde Formation & 7,754 & 928 & 909.00 & $11 / 07 / 1981$ & -- \\
\hline 82 & $\mathrm{SC} 01309117 \mathrm{CBCl}$ & Colorado Westmoreland Inc. & Mesaverde Formation & 7,422 & 690 & 534.00 & $07 / 21 / 1982$ & -- \\
\hline 83 & SC01309118BDA1 & Colorado Westmoreland Inc. & Mesaverde Formation & 8,597 & 1,963 & Dry & -- & -- \\
\hline 84 & SC01309210CDA1 & Colorado Westmoreland Inc. & Mesaverde Formation & 8,578 & 2,035 & $1,199.00$ & $07 / 21 / 1982$ & -- \\
\hline 85 & SC01309211CBA1 & Colorado Westmoreland Inc. & Mesaverde Formation & 8,253 & 1,420 & -- & -- & -- \\
\hline 86 & SC01309211DBB1 & Colorado Westmoreland Inc. & Mesaverde Formation & 8,565 & 2,073 & $1,140.00$ & $07 / 21 / 1982$ & - \\
\hline 87 & $S C 01309214 A A B 1$ & Colorado Westmoreland Inc. & Mesaverde Formation & 7,932 & 1,345 & $1,238.00$ & $07 / 29 / 1982$ & $07 / 29 / 1982$ \\
\hline 88 & $\mathrm{SCO} 1309214 \mathrm{CBD} 1$ & U.S. Bureau of Land Management & Mesaverde Formation & 7,480 & 509 & 148.95 & $09 / 13 / 1977$ & $08 / 16 / 1981$ \\
\hline 89 & SC01309214DBD1 & Colorado Westmoreland Inc. & Mesaverde Formation & 8,161 & 1,100 & $1,067.00$ & $07 / 21 / 1982$ & -- \\
\hline 90 & SC01309215ABD1 & Colorado Westmoreland Inc. & Mesaverde Formation & 8,310 & 1,655 & $1,044.00$ & $07 / 21 / 1982$ & $08 / 04 / 1982$ \\
\hline 91 & $\mathrm{SC0} 1309215 \mathrm{BACl}$ & Colorado Westmoreland Inc. & Mesaverde Formation & 8,193 & 1,545 & $1,372.00$ & $07 / 15 / 1982$ & $08 / 03 / 1982$ \\
\hline 92 & SC01309215BDD1 & Colorado Westmoreland Inc. & Mesaverde Formation & 8,196 & 1,475 & 999.00 & $07 / 25 / 1982$ & -- \\
\hline 93 & $\operatorname{SC} 01309215 \mathrm{DAC} 1$ & Colorado Westmoreland Inc. & Mesaverde Formation & 7,762 & 922 & 646.00 & $07 / 21 / 1982$ & -- \\
\hline 94 & $\mathrm{SC0} 1309215 \mathrm{DCC} 1$ & Colorado Westmoreland Inc. & Mesaverde Formation & 8,045 & 1,169 & 818.00 & $07 / 21 / 1982$ & -- \\
\hline 95 & SC01309219CDB 1 & Hotchkiss, Dick & Mesaverde Formation & 8,220 & 941 & 500.00 & $10 / 23 / 1977$ & -- \\
\hline 96 & SC01309220ACC1 & Hotchkiss, Dick & Mesaverde Formation & 8,280 & 700 & 494.00 & $09 / 19 / 1977$ & -- \\
\hline 97 & SC01309228ACB 1 & U.S. Bureau of Land Management & Mesaverde Formation & 8,170 & 604 & 245.25 & $09 / 17 / 1977$ & -- \\
\hline 98 & SC01309310DBD1 & Becker, Charles & Mesaverde Formation & 7,680 & 310 & 292.50 & $10 / 14 / 1977$ & -- \\
\hline 99 & $\mathrm{SC0} 1309316 \mathrm{AAD}$ & Becker, Charles & Mesaverde Formation & 7,480 & 560 & 157.80 & $10 / 04 / 1977$ & -- \\
\hline 100 & $\mathrm{SC} 01309324 \mathrm{CBA} 1$ & Scott, Arthur & Mesaverde Formation & 8,300 & 810 & 806.00 & $11 / 01 / 1977$ & -- \\
\hline 101 & SC01309325DAB 1 & Hotchkiss, Dick & Mesaverde Formation & 8,120 & 560 & 120.10 & $10 / 24 / 1977$ & -- \\
\hline 102 & SC01409108CCA1 & Schumard, Wesley & Mancos Shale & 5,915 & 10 & 0.00 & $03 / 29 / 1979$ & -- \\
\hline 40 & SC0 1409 109DAC 1 & Miller, C. K. & Mancos Shale & 6,226 & 66 & -- & -- & $09 / 17 / 1974$ \\
\hline 103 & SC01409118CAC1 & Elliot, Richard & Alluvium & 5,765 & 30 & 14.13 & $03 / 22 / 1979$ & -- \\
\hline 46 & SC01409202CAAl & & Glacial deposits & 6,030 & -- & 10.77 & $03 / 28 / 1979$ & -- \\
\hline 104 & SC01409209DBA 1 & Knight, Macdonald & Glacial deposits & 5,800 & 60 & 26.96 & $03 / 28 / 1979$ & -- \\
\hline 105 & SC01409209DBA2 & Azoulay, Lionel & Glacial deposits & 5,800 & 60 & 37.40 & $08 / 28 / 1979$ & -- \\
\hline
\end{tabular}


Table 3.--Hydrogeologic data for wells--Continued

\begin{tabular}{|c|c|c|c|c|c|c|c|c|}
\hline $\begin{array}{l}\text { Map } \\
\text { location } \\
\text { number } \\
\text { (see } \\
\text { plate } \\
1 \text { ) }\end{array}$ & $\begin{array}{l}\text { Local } \\
\text { identifier } \\
\text { (see } \\
\text { figure 2) }\end{array}$ & Owner & Principal aquifer & $\begin{array}{c}\text { Altitude } \\
\text { (feet) }\end{array}$ & $\begin{array}{r}\text { Well } \\
\text { depth } \\
\text { (feet) }\end{array}$ & $\begin{array}{c}\text { Depth } \\
\text { to } \\
\text { water } \\
\text { (feet) }\end{array}$ & $\begin{array}{l}\text { Date } \\
\text { water } \\
\text { level } \\
\text { measured }\end{array}$ & $\begin{array}{l}\text { Date } \\
\text { sampled } \\
\text { (see } \\
\text { table 5) }\end{array}$ \\
\hline 106 & SC01409214ABD1 & Chinn, C. R. & Mancos Shale & 5,680 & -- & 38.00 & $03 / 24 / 1978$ & $03 / 24 / 1978$ \\
\hline 53 & $\mathrm{SC} 01409216 \mathrm{CCA} 1$ & Ross, Harold & Dakota Sandstone & 5,480 & 1,386 & Flowing & -- & -- \\
\hline 55 & $\mathrm{SC} 01409219 \mathrm{ABC} 1$ & Roells, Loel & Glacial deposits & 5,675 & 39 & 27.89 & $03 / 24 / 1979$ & -- \\
\hline 107 & SC01409220ABD1 & Bramlett, J. & Alluvium & 5,510 & 24 & 10.00 & $09 / / 1974$ & $09 / 18 / 1974$ \\
\hline 108 & SC01409229CAAl & Wayne, Webster & Alluvium & 5,348 & 30 & 7.00 & $09 / / 1974$ & -- \\
\hline 109 & SC01409304BAD1 & Knight, Macdonald & Glacial deposits & 6,580 & 99 & 59.46 & $08 / 29 / 1979$ & -- \\
\hline 110 & SC01409305CCB 1 & Kinderkmcht, Alta & Glacial deposits & 6,680 & 185 & 110.40 & $03 / 24 / 1979$ & -- \\
\hline 111 & SC01409323BAB 1 & Mohan & Glacial deposits & 6,120 & 215 & 96.79 & $03 / 29 / 1979$ & -- \\
\hline 64 & $\mathrm{SC} 01409325 \mathrm{ABA} 1$ & Coutts, Mary & Glacial deposits & 5,620 & 38 & 24.78 & $03 / 24 / 1979$ & -- \\
\hline 112 & SC01409325CCD1 & Smith, Paul & Glacial deposits & 5,515 & 132 & 112.99 & $10 / 16 / 1977$ & -- \\
\hline 113 & $\operatorname{SC} 01409326 \mathrm{CCCl}$ & Blees, Dewey & Glacial deposits & 5,632 & 140 & 74.00 & $03 / 10 / 1978$ & $04 / 15 / 1978$ \\
\hline 114 & $\operatorname{sc0} 1409327 \mathrm{CCCl}$ & Barrett, Harry & -- & 5,680 & 119 & 107.00 & -- & -- \\
\hline 115 & $\mathrm{SC} 01409328 \mathrm{BBAl}$ & White, Melvin & Glacial deposits & 5,785 & 110 & 44.00 & $03 / 31 / 1978$ & $03 / 31 / 1978$ \\
\hline 116 & SC01509120ACC 1 & Todd, Lary & Mancos Shale & 6,400 & -- & 3.25 & $04 / 16 / 1978$ & $04 / 16 / 1978$ \\
\hline 117 & SC01509303AAA 1 & Roberts & Glacial deposits & 5,385 & -- & 67.14 & $03 / 23 / 1979$ & -- \\
\hline 118 & SC0 1509303AAA2 & Roberts & Glacial deposits & 5,485 & 113 & 71.00 & $03 / 23 / 1979$ & -- \\
\hline 119 & SC01509305AAA 1 & Greenwood, Ernest & Glacial deposits & 5,440 & -- & 13.84 & $03 / 23 / 1979$ & -- \\
\hline
\end{tabular}




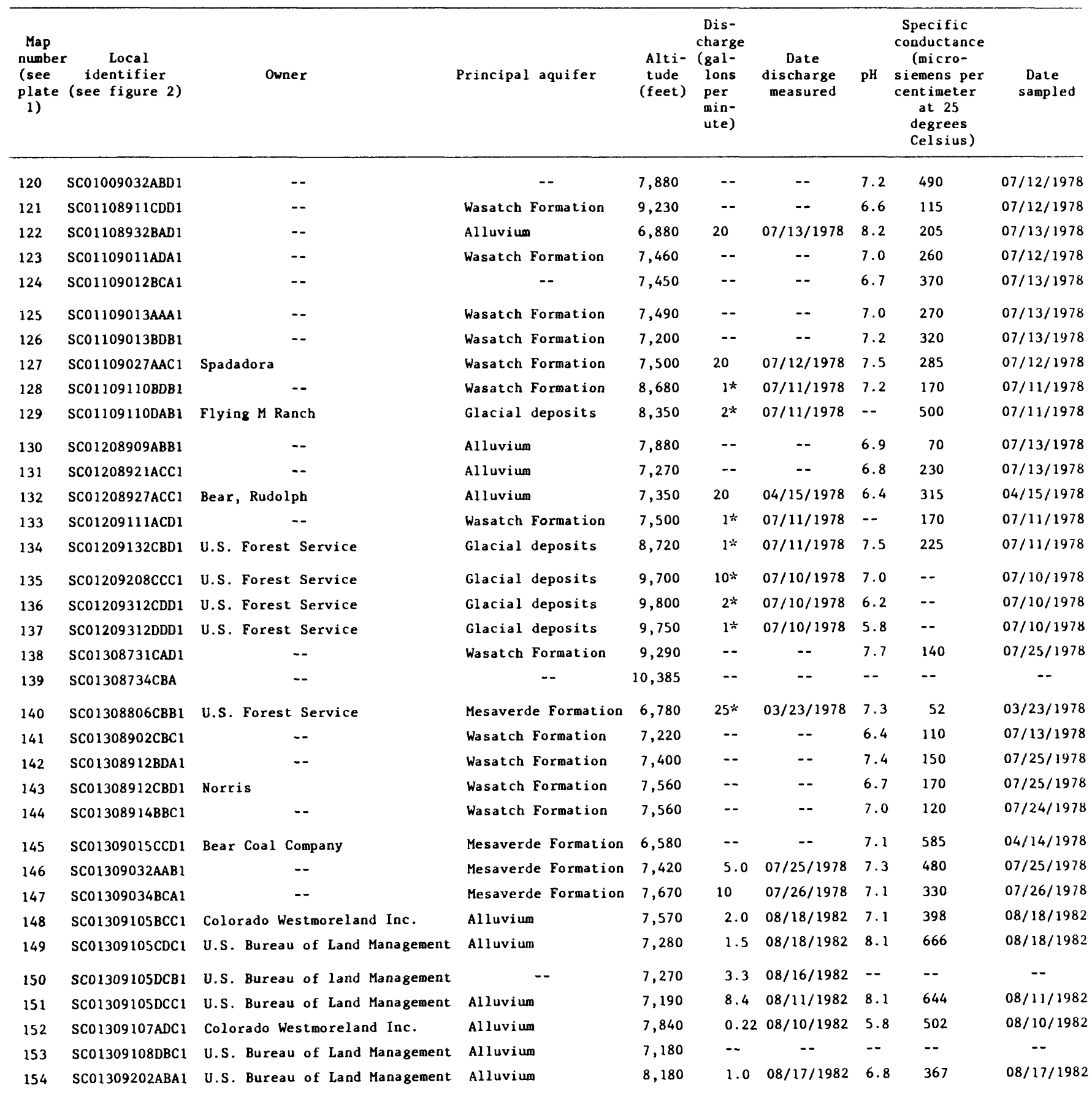


Table 4.--Hydrogeologic data for springs--Continued

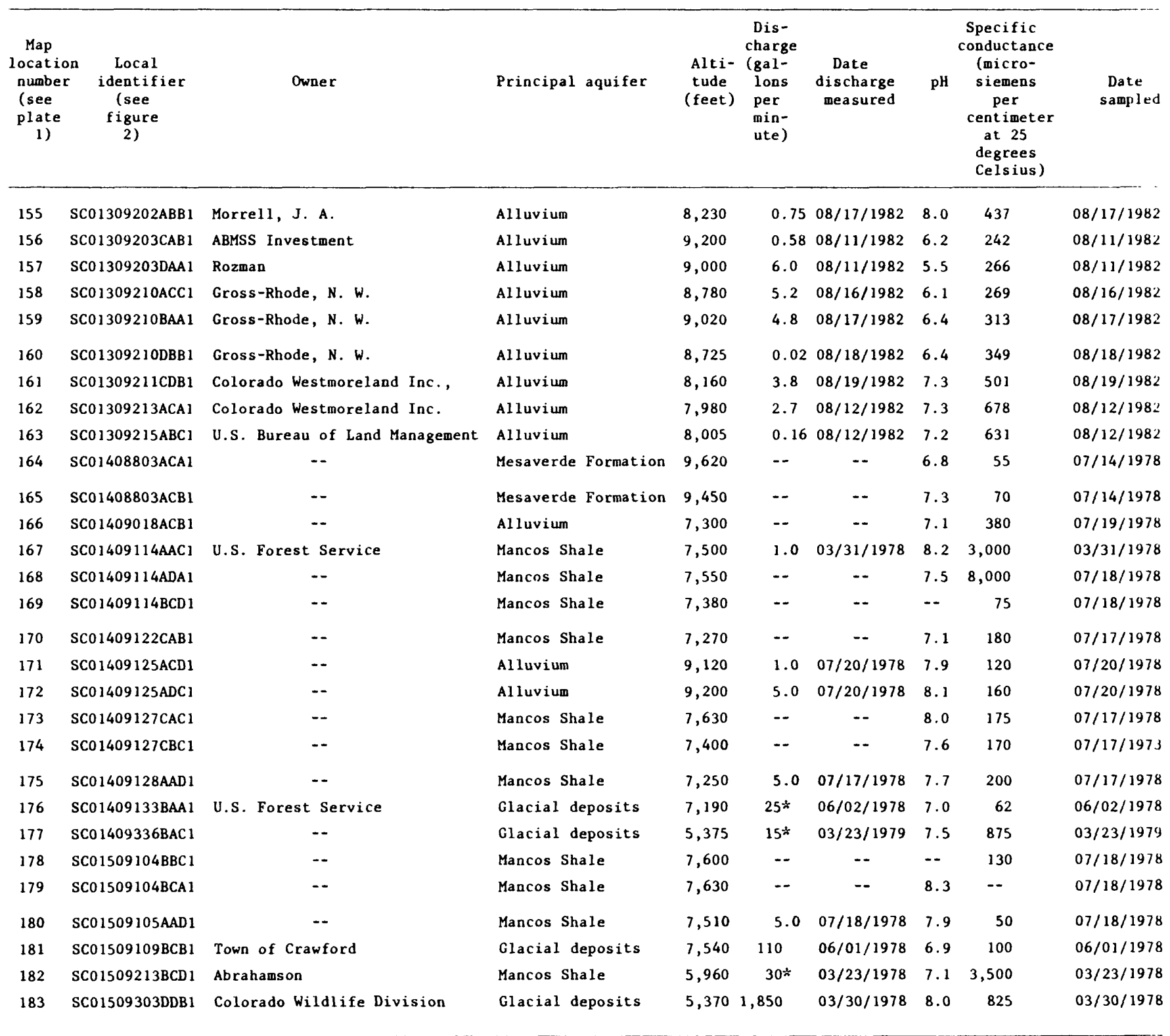

*Estimated discharge. 
Table 5.--Chemical analyses of water samples from wells and springs

[Local identifier, location of well or spring (see figure 2 ); $\mu \mathrm{s} / \mathrm{cm}$, microsiemens per centimeter at 25 degrees Celsius; ${ }^{\circ} \mathrm{C}$, degree Celsius; mg/L, milligrams per liter; $\mu_{g} / L$, micrograms per liter; <, less than; ND, not detected]

\begin{tabular}{|c|c|c|c|c|c|c|c|c|c|c|c|}
\hline $\begin{array}{l}\text { Map } \\
\text { location } \\
\text { number } \\
\text { (see } \\
\text { plate 1) }\end{array}$ & $\begin{array}{c}\text { Local } \\
\text { identifier }\end{array}$ & Principal aquifer & $\begin{array}{l}\text { Site } \\
\text { type }\end{array}$ & $\begin{array}{c}\text { Date } \\
\text { of } \\
\text { sample }\end{array}$ & $\begin{array}{l}\text { Well } \\
\text { depth } \\
\text { (feet) }\end{array}$ & $\begin{array}{c}\text { Specific } \\
\text { conductance } \\
(\mu \mathrm{s} / \mathrm{cm})\end{array}$ & $\mathrm{pH}$ & $\begin{array}{l}\text { Water } \\
\text { temper- } \\
\text { ature } \\
\left({ }^{\circ} \mathrm{C}\right)\end{array}$ & $\begin{array}{c}\text { Hard- } \\
\text { ness } \\
(\mathrm{mg} / \mathrm{L})\end{array}$ & $\underset{\left(\mathrm{mg}_{\mathrm{g}} / \mathrm{L}\right)}{\text { Calcium }}$ & $\begin{array}{l}\text { Magne- } \\
\text { si um } \\
(\mathrm{mg} / \mathrm{L})\end{array}$ \\
\hline 140 & $\mathrm{SC} 01308806 \mathrm{CBB} 1$ & Mesaverde Formation & Spring & $03-23-78$ & - & 52 & 7.3 & 4.5 & 36 & 11 & 2 \\
\hline 75 & $\mathrm{SC} 01308907 \mathrm{BDB} 1$ & Alluvium & Well & $05-29-74$ & 30 & 171 & 7.7 & 8.0 & 73 & 21 & 4.9 \\
\hline 76 & $\mathrm{SCO} 1309010 \mathrm{DCC} 1$ & Mesaverde Formation & Well & $05-29-74$ & 63 & 877 & 7.7 & 15.0 & 300 & 93 & 17 \\
\hline 145 & $\mathrm{SC} 01309015 \mathrm{CCD} 1$ & Mesaverde Formation & Spring & $04-14-78$ & - & 585 & 7.1 & 25.0 & 200 & 48 & 20 \\
\hline 148 & Sc01309105BCCl & Alluvium & Spring & $08-18-82$ & -- & 398 & 7.1 & 8.5 & 180 & 47 & 15 \\
\hline 149 & $\mathrm{SC0} 1309105 \mathrm{CDC1}$ & Alluvium & Spring & $08-18-82$ & -- & 666 & 8.1 & 10.5 & 240 & 60 & 22 \\
\hline 151 & $\mathrm{SC0} 1309105 \mathrm{DCC} 1$ & Alluvium & Spring & $08-11-82$ & - & 644 & 8.1 & 16.0 & 280 & 70 & 25 \\
\hline 152 & SC01309107ADC 1 & Alluvium & Spring & $08-10-82$ & - & 502 & 5.8 & 8.0 & 200 & 49 & 19 \\
\hline 154 & SC01309202ABA 1 & Alluvium & Spring & $08-17-82$ & - & 367 & 6.8 & 5.0 & 120 & 40 & 4.8 \\
\hline 155 & $\mathrm{SC} 01309202 \mathrm{ABB} 1$ & Alluvium & Spring & $08-17-82$ & -- & 437 & 8.0 & 8.0 & 160 & 51 & 8.7 \\
\hline 156 & SC01309203CAB1 & Alluvium & Spring & $08-11-82$ & -- & 242 & 6.2 & 11.5 & 120 & 28 & 11 \\
\hline 157 & SC01309203DAA1 & Alluvium & Spring & $08-11-82$ & -- & 266 & 5.5 & 13.0 & 91 & 25 & 6.8 \\
\hline 158 & $\mathrm{SC} 01309210 \mathrm{ACC} 1$ & Alluvium & Spring & $08-16-82$ & -- & 269 & 6.1 & 10.0 & 120 & 28 & 13 \\
\hline 159 & SC01309210BAAl & Alluvium & Spring & $08-17-82$ & -- & 313 & 6.4 & 12.0 & 140 & 33 & 15 \\
\hline 160 & SC01309210DBB1 & Alluvium & Spring & $08-18-82$ & -- & 349 & 6.4 & 15.5 & 180 & 41 & 19 \\
\hline 161 & $\mathrm{SC} 01309211 \mathrm{CDB} 1$ & Alluvium & Spring & $08-19-82$ & -- & 501 & 7.3 & 11.0 & 200 & 44 & 21 \\
\hline 162 & SC0 $1309213 A C A 1$ & Alluvium & Spring & $08-12-82$ & -- & 678 & 7.3 & 9.5 & 280 & 69 & 25 \\
\hline 87 & $\mathrm{SC0} 1309214 \mathrm{AAB} 1$ & Mesaverde Formation & Well & $07-29-82$ & 1,050 & 2,500 & 8.4 & 27.0 & 43 & 12 & 3.1 \\
\hline 88 & $\mathrm{SC} 01309214 \mathrm{CBD} 1$ & Mesaverde Formation & Well & $08-16-81$ & 683 & 750 & 7.3 & 11.0 & 150 & 38 & 14 \\
\hline 163 & $\mathrm{SC} 01309215 \mathrm{ABCl}$ & Alluvium & Spring & $08-12-82$ & -- & 631 & 7.2 & 15.0 & 300 & 84 & 21 \\
\hline 90 & $\mathrm{SC} 01309215 \mathrm{ABD} 1$ & Mesaverde Formation & Well & $08-04-82$ & 1,650 & 2,820 & 7.1 & 19.5 & 8 & 2.1 & .70 \\
\hline 93 & $\mathrm{SC0} 1309215 \mathrm{DACl}$ & Mesaverde Formation & Well & $08-03-82$ & -- & 4,230 & 7.5 & 21.5 & 37 & 9 & 3.2 \\
\hline 40 & SC0 1409109DAC1 & Mancos Shale & Well & $09-17-74$ & 66 & 9,420 & -- & 15.0 & 3,200 & 390 & 530 \\
\hline 167 & SC01409114AAC1 & Mancos Shale & Spring & $03-31-78$ & -- & 3,100 & 8.2 & 11.0 & 1,600 & 220 & 250 \\
\hline 176 & SC01409133BAAl & Glacial deposits & Spring & $06-02-78$ & - & 62 & 7.0 & 3.0 & 27 & 7.5 & 2 \\
\hline \multirow[t]{3}{*}{106} & $\mathrm{SC} 01409214 \mathrm{ABD} 1$ & Dakota Sandstone & Well & $05-21-75$ & 1,900 & 3,200 & 6.6 & 41.0 & 410 & 110 & 34 \\
\hline & & Dakota Sandstone & Well & $04-11-76$ & 1,900 & 3,100 & 6.5 & 42.0 & 410 & 110 & 32 \\
\hline & & Dakota Sandstone & Well & $03-24-78$ & 1,900 & 3,000 & 6.4 & 42.0 & 470 & 130 & 35 \\
\hline 107 & SC01409220ABD 1 & Alluvium & Well & $09-18-74$ & 24 & 2,700 & -- & 13.0 & 1,300 & 320 & 130 \\
\hline 113 & $\mathrm{SC} 01409326 \mathrm{CCC} 1$ & Glacial deposits & Well & $04-15-78$ & 140 & 860 & 7.5 & 14.5 & 310 & 64 & 37 \\
\hline 115 & $\mathrm{SC} 01409328 \mathrm{BBAl}$ & Glacial deposits & Well & $03-31-78$ & 110 & 535 & 7.5 & 13.0 & 280 & 56 & 34 \\
\hline 177 & $\mathrm{SC} 01409336 \mathrm{BAC} 1$ & Glacial deposits & Spring & $03-23-79$ & -- & 875 & 7.5 & 13.5 & 420 & 86 & 50 \\
\hline 181 & $\mathrm{SC} 01509109 \mathrm{BCB} 1$ & Glacial deposits & Spring & $06-01-78$ & -- & 100 & 6.9 & 7.5 & 38 & 12 & 1.9 \\
\hline 116 & $\mathrm{SC0} 1509120 \mathrm{ACCl}$ & Mancos Shale & Well & $04-16-78$ & - & 2,000 & 7.0 & 13.0 & 810 & 190 & 79 \\
\hline 182 & $\mathrm{SC0} 1509213 \mathrm{BCD} 1$ & Mancos Shale & Spring & $03-23-78$ & -- & 3,500 & 7.1 & 10.5 & 2,500 & 530 & 290 \\
\hline 183 & $\mathrm{SC} 01509303 \mathrm{DDB} 1$ & Glacial deposits & Spring & $03-30-78$ & -- & 825 & 8.0 & 14.0 & 350 & 60 & 48 \\
\hline
\end{tabular}


Table 5.--Chemical analyses of water samples from wells and springs--Continued

\begin{tabular}{|c|c|c|c|c|c|c|c|c|c|c|}
\hline Local identifier & $\begin{array}{c}\text { Date } \\
\text { of } \\
\text { sample }\end{array}$ & $\begin{array}{l}\text { Sodium } \\
\text { (mg/L) }\end{array}$ & $\begin{array}{l}\text { Percent } \\
\text { sodium }\end{array}$ & $\begin{array}{l}\text { Sodium } \\
\text { absorb- } \\
\text { tion } \\
\text { ratio }\end{array}$ & $\begin{array}{l}\text { Potas - } \\
\text { ium } \\
(\mathrm{mg} / \mathrm{L})\end{array}$ & $\begin{array}{l}\text { Bicar- } \\
\text { bonate } \\
\text { (mg/L) }\end{array}$ & $\begin{array}{l}\text { Field } \\
\text { alka- } \\
\text { linity } \\
(\mathrm{mg} / \mathrm{L})\end{array}$ & $\begin{array}{r}\text { Sulf fate } \\
(\mathrm{mg} / \mathrm{L})\end{array}$ & $\begin{array}{l}\text { Chlo- } \\
\text { ride } \\
\text { (mg/L }\end{array}$ & $\begin{array}{l}\text { Fluo- } \\
\text { ride } \\
\text { (mg/L) }\end{array}$ \\
\hline $\mathrm{SC0} 1308806 \mathrm{CBB} 1$ & $03-23-78$ & 2.9 & 15 & 0.2 & 0.40 & 41 & 34 & 5.7 & 1.5 & 0.10 \\
\hline 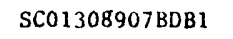 & $05-29-74$ & 9.6 & 22 & .5 & 1.0 & 97 & 80 & 7.4 & .90 & .10 \\
\hline SC01309010DCC1 & $05-29-74$ & 83 & 37 & 2 & 1.8 & 380 & 314 & 110 & 30 & $<.10$ \\
\hline $\mathrm{SCO} 1309015 \mathrm{CCD} 1$ & $04-14-78$ & 66 & 41 & 2 & 1.9 & 350 & 290 & 50 & 2.9 & .20 \\
\hline $\mathrm{SC0} 1309105 \mathrm{BCC} 1$ & $08-18-82$ & 45 & 35 & 2 & 1.2 & -- & -- & 25 & 3.7 & .20 \\
\hline $\operatorname{SC0} 1309105 \mathrm{CDC} 1$ & $08-18-82$ & 50 & 31 & 1 & 2.2 & -- & -- & 23 & 4.4 & .20 \\
\hline $\mathrm{SC0} 1309105 \mathrm{DCC} 1$ & $08-11-82$ & 55 & 30 & 1 & 2.6 & -- & -- & 22 & 5.9 & .20 \\
\hline SC01309107ADC1 & $08-10-82$ & 42 & 31 & 1 & 2.2 & -- & -- & 14 & 4.0 & .30 \\
\hline SC01309202ABA1 & $08-17-82$ & 34 & 38 & 1 & 2.5 & -- & -- & 12 & 1.0 & .20 \\
\hline SC01309202ABB 1 & $08-17-82$ & 25 & 25 & .9 & 2.3 & -- & -- & 20 & 1.4 & .20 \\
\hline $\mathrm{SCO} 1309203 \mathrm{CAB} 1$ & $08-11-82$ & 7 & 11 & .3 & 2.2 & -- & -- & $<5.0$ & .60 & .10 \\
\hline SC01309203DAAI & $08-11-82$ & 24 & 36 & 1 & .90 & -- & -- & 5.0 & 3.8 & .20 \\
\hline $\mathrm{SC0} 1309210 \mathrm{ACC} 1$ & $08-16-82$ & 7.2 & 11 & .3 & 2.1 & -- & -- & $<5.0$ & 1.3 & .20 \\
\hline SCO1309210BAA1 & $08-17-82$ & 9.2 & 12 & .3 & 2.8 & -- & -- & $<5.0$ & 1.4 & .20 \\
\hline SC01309210DBB1 & $08-18-82$ & 9.6 & 10 & .3 & 1.7 & -- & -- & 6.0 & 2.4 & .20 \\
\hline SC01309211CDB1 & $08-19-82$ & 38 & 30 & 1 & 1.0 & -- & -- & 9.0 & 3.0 & .20 \\
\hline SC01309213ACA1 & $08-12-82$ & 56 & 31 & 2 & 1.7 & -- & -- & 62 & 6.0 & .20 \\
\hline SC01309214AAB1 & $07-29-82$ & 650 & 95 & 45 & 23 & -- & -- & 43 & 130 & 1.4 \\
\hline SC01309214CBD1 & $08-16-81$ & 140 & 66 & 5 & 2.8 & -- & -- & 50 & 4.4 & .30 \\
\hline SC01309215ABC1 & $08-12-82$ & 24 & 15 & .6 & 1.2 & -- & -- & 36 & 6.3 & .30 \\
\hline SC01309215ABD1 & $08-04-82$ & 750 & 99 & 120 & 6.5 & -- & -- & $<5.0$ & 56 & 3.5 \\
\hline SC01309215DAC1 & $08-03-82$ & 1,300 & 98 & 98 & 13 & -- & -- & 11 & 180 & 1.9 \\
\hline SC01409109DAC1 & $09-17-74$ & 1,500 & 51 & 12 & 25 & 940 & 769 & 5,200 & 88 & .30 \\
\hline SC01409114AAC1 & $03-31-78$ & 410 & 36 & 5 & 7.8 & 340 & 280 & 2,000 & 27 & .60 \\
\hline SC01409133BAAl & $06-02-78$ & 2.9 & 19 & .3 & .10 & 30 & 25 & 5.5 & .70 & $<.10$ \\
\hline \multirow[t]{3}{*}{ SC01409214ABD1 } & $05-21-75$ & 610 & 74 & 13 & 36 & 1,540 & 1,260 & 58 & 370 & 2.4 \\
\hline & $04-11-76$ & 570 & 73 & 13 & 41 & 760 & 896 & -- & 400 & 2.5 \\
\hline & $03-24-78$ & 620 & 72 & 13 & 44 & 1,520 & 1,250 & 110 & 380 & 2.2 \\
\hline SC01409220ABD1 & $09-18-74$ & 190 & 23 & 2 & 11 & 370 & 304 & 1,400 & 14 & .60 \\
\hline $\mathrm{SC} 01409326 \mathrm{CCC} 1$ & $04-15-78$ & 110 & 42 & 3 & 12 & 410 & 340 & 210 & 6.4 & .50 \\
\hline SC01409328BBA1 & $03-31-78$ & 19 & 12 & .5 & 7.7 & 310 & 250 & 71 & 2.1 & 1.1 \\
\hline SC01409336BACl & $03-23-79$ & 92 & 31 & 2 & 13 & -- & 340 & 260 & 13 & .50 \\
\hline SC01509 109BCB1 & $06-01-78$ & 5.1 & 23 & .4 & .10 & 51 & 42 & 7.4 & 3.7 & .10 \\
\hline SC01509120ACC1 & $04-16-78$ & 290 & 44 & 5 & 12 & 560 & 460 & 870 & 57 & 1.2 \\
\hline $\mathrm{SC0} 1509213 \mathrm{BCD} 1$ & $03-23-78$ & 420 & 27 & 4 & 14 & 450 & 370 & 2,800 & 6.0 & .80 \\
\hline $\mathrm{SC} 01509303 \mathrm{DDB} 1$ & $03-30-78$ & 85 & 33 & 2 & 17 & 430 & 350 & 160 & 6.3 & .60 \\
\hline
\end{tabular}


Table 5.--Chemical analyses of water samples from wells and springs--Continued

\begin{tabular}{|c|c|c|c|c|c|c|c|c|c|c|}
\hline Local identifier & $\begin{array}{c}\text { Date } \\
\text { of } \\
\text { sample }\end{array}$ & $\begin{array}{l}\text { Dis- } \\
\text { solved } \\
\text { solids } \\
(\mathrm{mg} / \mathrm{L})\end{array}$ & $\begin{array}{l}\text { Nitrite } \\
\text { and ni- } \\
\text { trate } \\
\text { as ni- } \\
\text { trogen } \\
\text { (mg/L) }\end{array}$ & $\begin{array}{l}\text { Ortho } \\
\text { phos- } \\
\text { phorus } \\
\text { (mg/L) }\end{array}$ & $\begin{array}{l}\text { Ortho } \\
\text { phos- } \\
\text { phate } \\
\left(m_{g} / L\right)\end{array}$ & $\begin{array}{l}\text { Alum- } \\
\text { inum } \\
\left(u_{g} / L\right)\end{array}$ & $\begin{array}{l}\text { Boron } \\
(u g / L)\end{array}$ & $\begin{array}{c}\text { Cadmium } \\
\text { (ug/L) }\end{array}$ & $\begin{array}{l}\text { Chro- } \\
\text { mium } \\
\left(u_{g} / L\right)\end{array}$ & $\begin{array}{l}\text { Coppe } \\
\text { (ug/L }\end{array}$ \\
\hline $\mathrm{SC} 01308806 \mathrm{CBB} 1$ & $03-23-78$ & 56 & .390 & .030 & .09 & 80 & 0 & $\mathrm{ND}$ & -- & 2 \\
\hline $\mathrm{SC} 01308907 \mathrm{BDB} 1$ & $05-29-74$ & 110 & $<.100$ & .020 & .06 & -- & $<20$ & -- & -- & -- \\
\hline SC01309010DCC1 & $05-29-74$ & 540 & .060 & .010 & .03 & -- & 50 & -- & -- & -- \\
\hline SC01309015CCD 1 & $04-14-78$ & 370 & .350 & .010 & .03 & $<100$ & 50 & 4 & -- & 14 \\
\hline SC01309105BCC 1 & $08-18-82$ & 290 & .210 & .020 & .06 & $<10$ & 130 & $<1$ & $<10$ & $<1$ \\
\hline $\mathrm{SC} 01309105 \mathrm{CDC} 1$ & $08-18-82$ & 370 & .240 & .090 & .28 & $<10$ & 130 & $<1$ & $<10$ & $<1$ \\
\hline SC01309105DCC 1 & $08-11-82$ & 400 & $<.100$ & -- & -- & 10 & 40 & $<1$ & $<10$ & $<1$ \\
\hline SC01309107ADC 1 & $08-10-82$ & 330 & .500 & $<.010$ & -- & $<10$ & 10 & $<1$ & $<10$ & $<1$ \\
\hline SC01309202ABA1 & $08-17-82$ & 220 & .110 & .010 & .03 & 10 & 130 & $<1$ & $<10$ & $<1$ \\
\hline $\mathrm{SC} 01309202 \mathrm{ABB} 1$ & $08-17-82$ & 250 & $<.100$ & $<.010$ & -- & 10 & 130 & $<1$ & $<10$ & $<1$ \\
\hline SC01309203CAB 1 & $08-11-82$ & - & .190 & .030 & .09 & 20 & $<10$ & $<1$ & $<10$ & 3 \\
\hline SC01309203DAA 1 & $08-11-82$ & 170 & .790 & - & -- & 20 & $<10$ & $<1$ & $<10$ & 11 \\
\hline SC01309210ACC 1 & $08-16-82$ & -- & .440 & .270 & .83 & $<10$ & 110 & $<1$ & $<10$ & 1 \\
\hline SC01309210BAA 1 & $08-17-82$ & -- & .270 & .120 & .37 & 10 & 110 & $<1$ & 10 & 4 \\
\hline SC01309210DBB 1 & $08-18-82$ & 230 & $<.100$ & .030 & .09 & 10 & 120 & 1 & $<10$ & 1 \\
\hline $\mathrm{SC} 01309211 \mathrm{CDB} 1$ & $08-19-82$ & 310 & 2.10 & .020 & .06 & 10 & 110 & $<1$ & $<10$ & $<1$ \\
\hline SC01309213ACA1 & $08-12-82$ & 410 & .240 & -- & -- & 20 & 30 & $<1$ & $<10$ & $<1$ \\
\hline SC01309214AAB1 & $07-29-82$ & 1,700 & .390 & .080 & .25 & 120 & 1,000 & $<1$ & $<10$ & 23 \\
\hline SC01309214CBD 1 & $08-16-81$ & 490 & .190 & .030 & .09 & 10 & 80 & 1 & 10 & 4 \\
\hline $\mathrm{SC} 01309215 \mathrm{ABC} 1$ & $08-12-82$ & 370 & $<.100$ & -- & -- & 10 & 30 & $<1$ & $<10$ & 1 \\
\hline $\mathrm{SC} 01309215 \mathrm{ABD} 1$ & $08-04-82$ & - & $<.100$ & .010 & .03 & $<10$ & 2,000 & $<1$ & $<10$ & $<1$ \\
\hline SC01309215DAC 1 & $08-03-82$ & 3,200 & $<.100$ & .020 & .06 & 40 & 2,000 & $<10$ & 10 & 1 \\
\hline SC01409 109DAC 1 & $09-17-74$ & 8,200 & 3.80 & .030 & .09 & -- & 1,000 & -- & - & -- \\
\hline SC01409114AAC 1 & $03-31-78$ & 3,100 & - & .010 & .03 & 20 & 330 & 2 & $<20$ & 4 \\
\hline SC01409 133BAA1 & $06-02-78$ & 43 & .600 & .040 & .12 & 10 & $<20$ & $\mathrm{ND}$ & - & ND \\
\hline \multirow[t]{3}{*}{ SC01409214ABD1 } & $05-21-75$ & 2,000 & .010 & .040 & .12 & - & - & -- & -- & -- \\
\hline & $04-11-76$ & -- & $<.100$ & .020 & .06 & -- & 1,700 & -- & -- & - \\
\hline & $03-24-78$ & 2,100 & .570 & .020 & .06 & 10 & 1,800 & $\mathrm{ND}$ & -- & $\mathrm{ND}$ \\
\hline SC01409220ABD 1 & $09-18-74$ & 2,300 & 1.60 & .060 & .18 & -- & 360 & -- & -- & - \\
\hline $\operatorname{SC} 01409326 \mathrm{CCC} 1$ & $04-15-78$ & 680 & 1.10 & .020 & .06 & $<100$ & 180 & $<2$ & -- & 2 \\
\hline SC01409328BBAI & $03-31-78$ & 380 & .380 & .010 & .03 & 10 & 90 & $\mathrm{ND}$ & - & 4 \\
\hline $\mathrm{SC} 01409336 \mathrm{BAC} 1$ & $03-23-79$ & 760 & 3.20 & .040 & .12 & 10 & 130 & -- & -- & ND \\
\hline SC01509109BCB 1 & $06-01-78$ & 69 & .430 & .030 & .09 & 40 & 70 & $\mathrm{ND}$ & - & $<2$ \\
\hline SC01509120ACC 1 & $04-16-78$ & 1,800 & .130 & $<.010$ & .00 & $<100$ & 770 & $<2$ & -- & ND \\
\hline $\mathrm{SC} 01509213 \mathrm{BCD} 1$ & $03-23-78$ & 4,300 & 4.00 & .010 & .03 & $<100$ & 590 & $<2$ & -- & 6 \\
\hline SC01509303DDB 1 & $03-30-78$ & 630 & 1.50 & .020 & .06 & 10 & 150 & $\mathrm{ND}$ & -- & 3 \\
\hline
\end{tabular}


Table 5.--Chemical analyses of water samples--Continued

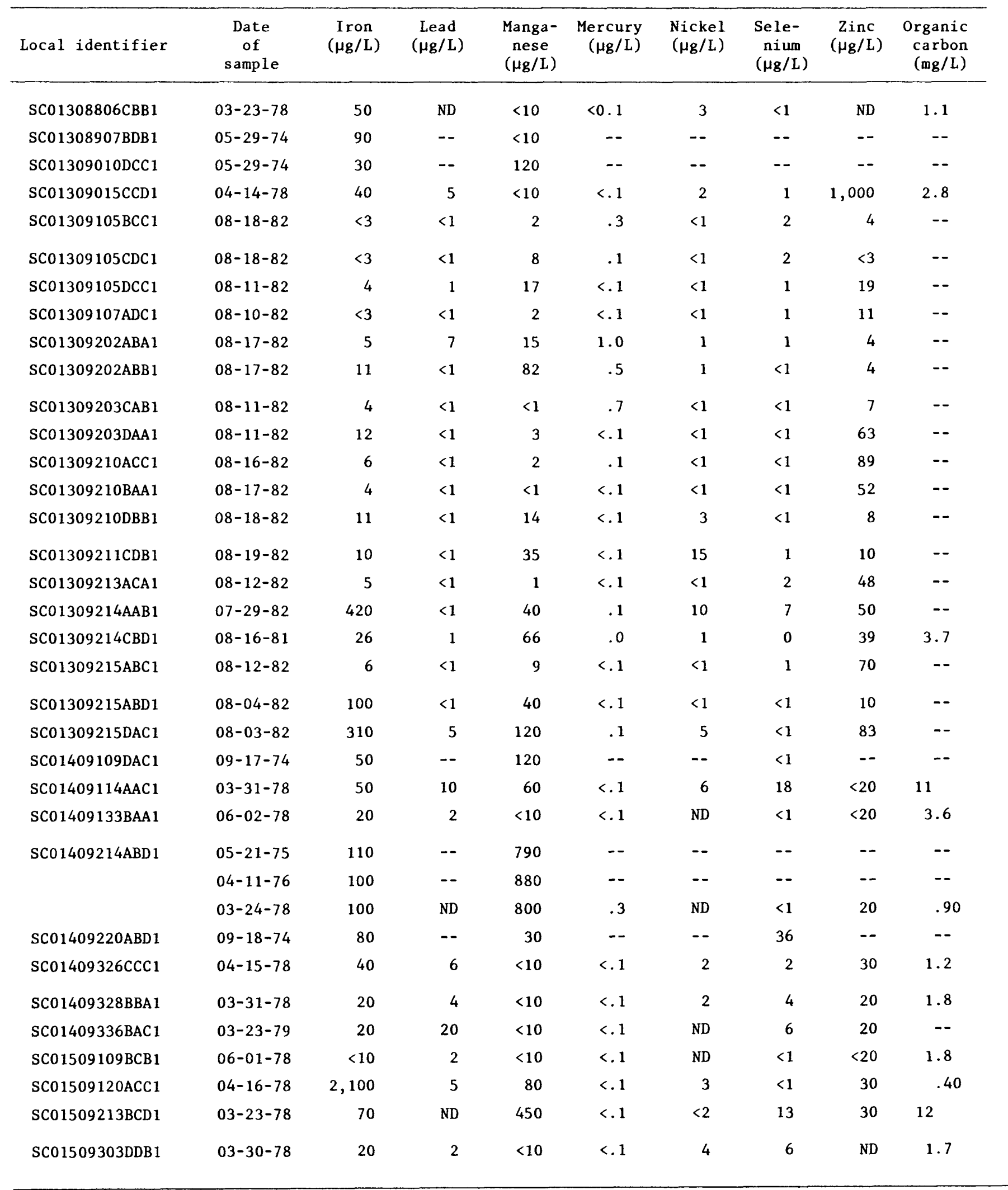

